\begin{tabular}{ccc}
\hline & International Journal of Advanced Geosciences, 8 (2) (2020) 259-262 \\
SPC & Website $w w w$. sciencepubco.com/index.php/IJAG \\
Research paper & Resciences \\
\hline
\end{tabular}

\title{
Behavior of the clinopyroxenes trace elements in spinel-lherzolite xenoliths from Liri (Kapsiki plateau, Cameroon line)
}

\author{
Nguihdama Dagwai ${ }^{1}$ *, Kamgang Pierre ${ }^{2}$, Mbowou Gbambié Isaac Bertrand ${ }^{3}$, \\ Chazot Gilles ${ }^{4}$, Ngounouno Ismaïla ${ }^{3}$ \\ ${ }^{1}$ Ecole Normale Supérieure, Université de Maroua, Cameroun \\ ${ }^{2}$ Département des sciences de la Terre, Faculté des Sciences, Université de Yaoundé I, Yaoundé, Cameroun \\ ${ }^{3}$ Ecole de Géologie et d'Exploitation Minière (EGEM), Département de Mines et de la Géologie, \\ Université de Ngaoundéré, Meiganga, Cameroun \\ 4 Université Européenne de Bretagne, Brest, France \\ *Corresponding authorE-mail: da_nguihdama76@yahoo.fr
}

\begin{abstract}
Spinel-lherzolite xenoliths trapped within the alkali basalts flow in the Liri region (Kapsiki Plateau) have a protogranular texture and consist of olivine, orthopyroxene, clinopyroxene and spinel crystals. These xenoliths are residues of partial melting of the primitive mantle, with the low titanium content in clinopyroxene crystals $\left(\mathrm{TiO}_{2}<0.5 \mathrm{wt} . \%\right)$. The clinopyroxene of the spinel-lherzolite xenoliths from Liri, are divided into two distinct groups according to their trace element characteristics. The variations in the rare earths elements make it possible to classify the different clynopyroxenes in two groups: the first group consisting of the samples of Liri (Liri 1, Liri 02, Liri 3, Liri 05 and Liri 5) rich in light rare earths elements (LREEs), with ratios (Ce/Yb)N normalized which vary between 3.00 and 7.78 . It is probably a cryptic metasomatism due to the absence of hydrated minerals (such as amphibole) which caused these enrichments. The second group comprises samples of Liri (Liri 01, Liri 2, Liri 04, Liri 4) depleted in light rare earths elements, with the ratio in $(\mathrm{Ce} / \mathrm{Yb}) \mathrm{N}<1.2$. This depletion in rare earths elements results from the extraction of the melting liquid.
\end{abstract}

Keywords: Spinel-Lherzolite Xenoliths; Clinopyroxene; Cryptic Metasomatism; Liri; Cameroon Line.

\section{Introduction}

Peridotite nodules broken to the surface by alkaline basalts provide us direct information on the processes and composition of the upper mantle. These nodules constitute the major source of information concerning the state of stress, pressure and temperature in the upper mantle. Mantle xenoliths occur in the basaltic plug from Liri (south of the Kapsiki Plateau, Cameroon Line). Alkali basaltic lavas exhumed these ultramafic xenoliths consisting of olivine, clynopyroxene, orthopyroxene and spinel. In the formerly petrological study on the Liri sector, major and trace elements of the host-basalt and the mineral chemistry of the spinel-lherzolite xenoliths are presented. According to these data, [1] proposed that the spinel-lherzolite xenoliths from Liri are the residues of partial melting of an initial mantle with a small degree of partial melting. However, clinopyroxene is a major host for many incompatible trace elements in peridotite xenoliths and as such its trace-element composition is a useful indicator of chemical modification in the mantle. In this respect, clinopyroxenes in mantle xenoliths from Liri would furnish opportunities to better understand Liri's peridotite formation processes. Since crystal chemical studies have demonstrated that site configurations may be related to specific suites of possible mantle residue from partial melting and metasomatism ([2]; [3]).

This study is focused on the behavior of the clinopyroxenes trace elements, analyzed in spinel lherzolte xenoliths from Liri, in order to establish their petrological origin and thermobarometric stability conditions in the mantle, according to the mineral chemistry and crystal structure.

\section{Geological setting}

The Kapsiki plateau (altitude $\approx 1000 \mathrm{~m}$ ) is a volcanic zone located northern of the "Cameroon Line" [4]. The Precambrian base of this area is intersected by numerous needles and dykes of trachyte, phonolite and rhyolite, and partially covered by basaltic flows. The age of the basalts is included between 33.2 $\pm 1.3 \mathrm{Ma}$ [5] and 27.0 $\pm 0.5 \mathrm{Ma}$ [6]. The trachytes were dated at 29.6 $\pm 0.6 \mathrm{Ma}$ [6] and 35.3 $\pm 2.4 \mathrm{Ma}$ [5] The age of rhyolites is between $32 \pm 0.5 \mathrm{Ma}$ and 29.0 Ma [5]. The presence of xenoliths in the Liri sector (south of the Kapsiki Plateau) was initially reported by [7]. According to the work of [8], it is proved that the structural and Geophysical (gravimetric and seismological) features of the granite-gneissic base complex are still poorly defined. 
The Liri sector is located along the Cameroon Line with a basement constituted of granite and gneiss (Fig. 1). This basement is crossed by faults and locally covered by basaltic lava flows. The lava flows are broken up into the small centimetric blocks. The spinel-lherzolite xenoliths (size: 7-30 cm) with sub-rounded shapes were discovered in these dark basaltic lavas.

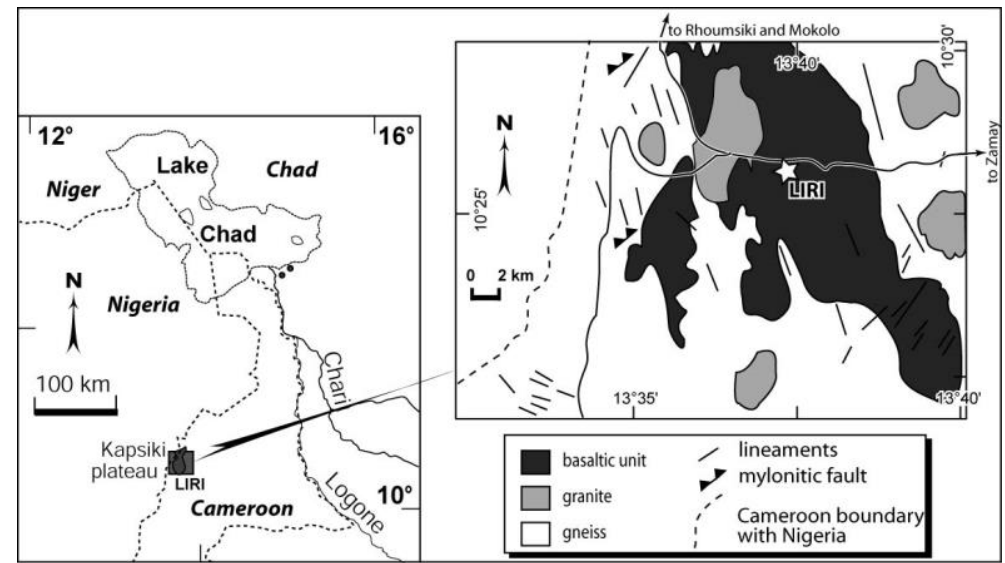

Fig. 1: Location of the Ultramafic Xenoliths from Liri Within the Kapsiki Plateau and the Geological Sketch of the Studied Sector.

\section{Analytical methods}

The polished thin sections of the different rock-types were observed under an Olympus BH2-HLSH microscope. The minerals of the different thin sections were observed at magnifications x5, x10, x25 and x50. Chemical analyzes ("Université de Bretagne OccidentaleBrest, France") of major elements were performed using an electron microprobe with beams of: 10 and $40 \mu \mathrm{m}, 15 \mathrm{kV}$ and $15 \mathrm{nA}$. Errors considered for these analyzes are between 5\% and $10 \%$ of measured values $<1 \%$ and between $1 \%$ and $5 \%$ of the measured values $>1 \%$. Measurements of trace elements of the different phases have been produced using a technique laser ablation of a mass spectrometer coupled plasma source (LA-ICP-MS). The analyzes are done on polished sections. Before each analysis, the samples are metallized with carbon. Then a very fine incident beam of electrons comes into contact with the sample. In order to test the homogeneity of the peridotite minerals, several grains on the samples were analyzed. To verify the zonation in composition, we analyzed several points in the same grain. Overall, no chemical variation from one grain to another in the sample was observed for olivine and spinel. The olivine and spinel analyzes were performed punctually in the core of the crystals.

\section{Results}

Spinel-lherzolite xenoliths from Liri (south of the Kapsiki Plateau) have a protogranular texture and consist of olivine (50-60 vol.\%), orthopyroxene (20-25 vol.\%), clinopyroxene (10-16 vol\%) and spinel (2-4 vol.\%) crystals [9]. Clinopyroxene phases occur in these lherzolite xenoliths as interstitial crystals between olivine and orthopyroxene. These clinopyroxene crystals (Fig. 2, Table 1) have the compositions of Cr-diopside (Wo45.67-47.99En53.92-51.77 Fs0.41-0.24) and augite (W043.85-44.86En54.13-53.44Fs $2.03-1.70$ ) with M2-Site characterized by high $\mathrm{Ca}(\approx 0.830$ atoms per formula unit, a.p.f.u. $)$ and $\mathrm{Mg}_{2}(\approx 0.850$ a.f.u. $)$ components (Tab. 1$)$.

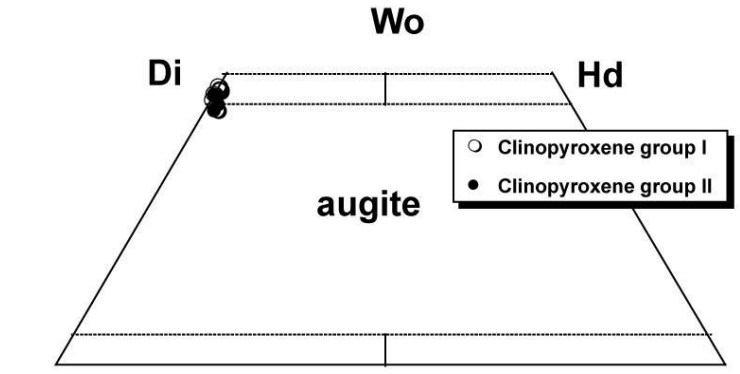

En

Fs

Fig. 2: Compositions of the Clinopyroxenes Analyzed in the Spinel-Xenoliths of Liri.

Two groups (I and II) of clinopyroxene are identified according to the trace elements contents. In some crystals (group I) the trace elements are enriched than in the others (see Table 2). Excepted for Er and Yb contents, where the compositions are similar in the both groups; the seggragation are shown in the normalized REE patterns (Fig. 3). Even the Sr and Zr contents (see Table 2) are enriched in the group I clynopyroxenes from the spinel-xenoliths of Liri.

Table 1: Chemical Analyses of Major Element, Cation Partition Among of T, M1, M2 Sites and V(Cell), V(M1) Volume for Liri Clinopyroxenes

\begin{tabular}{|c|c|c|c|c|c|c|c|c|c|c|}
\hline Samples & LIRI-01 & LIRI-02 & LIRI-04 & LIRI-05 & LIRI1 & LIRI2 & LIRI3 & LIRI4 & LIRI5 & LIRI5 \\
\hline $\mathrm{SiO}_{2}(\mathrm{wt} \%)$ & 52.28 & 51.59 & 52.48 & 52.63 & 52.75 & 52.05 & 52.13 & 51.26 & 52.68 & 51.42 \\
\hline $\mathrm{TiO}_{2}$ & 0.26 & 0.32 & 0.23 & 0.30 & 0.22 & 0.16 & 0.22 & 0.27 & 0.29 & 0.45 \\
\hline $\mathrm{Al}_{2} \mathrm{O}_{3}$ & 5.14 & 5.87 & 5.04 & 4.99 & 5.14 & 5.05 & 4.90 & 5.84 & 5.22 & 5.87 \\
\hline $\mathrm{Cr}_{2} \mathrm{O}_{3}$ & 0.93 & 1.01 & 0.91 & 0.90 & 1.00 & 1.02 & 0.94 & 1.14 & 0.97 & 0.94 \\
\hline $\mathrm{FeO} *$ & 2.64 & 2.76 & 2.97 & 2.26 & 2.35 & 2.50 & 2.35 & 3.24 & 2.10 & 3.30 \\
\hline $\mathrm{MnO}$ & 0.10 & 0.10 & 0.05 & 0.05 & 0.04 & 0.02 & 0.12 & 0.14 & 0.12 & 0.14 \\
\hline $\mathrm{MgO}$ & 15.84 & 15.66 & 16.15 & 15.68 & 15.50 & 15.86 & 15.74 & 15.80 & 15.46 & 15.84 \\
\hline $\mathrm{CaO}$ & 21.50 & 21.42 & 21.18 & 22.14 & 21.80 & 21.78 & 21.63 & 20.85 & 22.24 & 20.81 \\
\hline
\end{tabular}




\begin{tabular}{|c|c|c|c|c|c|c|c|c|c|c|}
\hline $\mathrm{Na}_{2} \mathrm{O}$ & 1.37 & 1.36 & 1.31 & 1.40 & 1.58 & 1.35 & 1.41 & 1.23 & 1.50 & 1.25 \\
\hline \multicolumn{10}{|l|}{ T-Site } & 100.03 \\
\hline Si(a.p.f.u) & 1.886 & 1.861 & 1.889 & 1.893 & 1.896 & 1.882 & & 1.858 & 1.890 & 1.859 \\
\hline $\mathrm{Al}^{\mathrm{iv}}$ & 0.114 & 0.139 & 0.111 & 0.107 & 0.104 & 0.118 & 0.109 & 0.142 & 0.110 & 0.141 \\
\hline Sum & 2.000 & 2.000 & 2.000 & 2.000 & 2.000 & 2.000 & 2.000 & 2.000 & 2.000 & 2.000 \\
\hline \multicolumn{11}{|l|}{ M1-Site } \\
\hline $\mathrm{Al}^{\mathrm{vi}}$ & 0.105 & 0.111 & 0.102 & 0.105 & 0.114 & 0.097 & 0.101 & 0.107 & 0.111 & 0.109 \\
\hline $\mathrm{Fe}^{3+}$ & 0.064 & 0.076 & 0.062 & 0.057 & 0.060 & 0.076 & 0.069 & 0.073 & 0.060 & 0.068 \\
\hline $\mathrm{Ti}$ & 0.007 & 0.009 & 0.006 & 0.008 & 0.006 & 0.004 & 0.006 & 0.007 & 0.008 & 0.012 \\
\hline $\mathrm{Cr}$ & 0.027 & 0.029 & 0.026 & 0.026 & 0.028 & 0.029 & 0.027 & 0.033 & 0.028 & 0.027 \\
\hline $\mathrm{Mg}_{1}$ & 0.742 & 0.708 & 0.740 & 0.767 & 0.753 & 0.731 & 0.744 & 0.705 & 0.760 & 0.713 \\
\hline $\mathrm{Fe}_{1}$ & 0.055 & 0.067 & 0.063 & 0.037 & 0.039 & 0.062 & 0.054 & 0.074 & 0.033 & 0.070 \\
\hline Sum & 1.000 & 1.000 & 1.000 & 1.000 & 1.000 & 1.000 & 1.000 & 1.000 & 1.000 & 1.000 \\
\hline \multicolumn{11}{|l|}{ M2-Site } \\
\hline $\mathrm{Mg}_{2}$ & 0.069 & 0.074 & 0.088 & 0.047 & 0.048 & 0.062 & 0.056 & 0.097 & 0.036 & 0.098 \\
\hline $\mathrm{Fe}_{2}$ & 0.001 & 0.001 & 0.003 & 0.001 & 0.001 & 0.000 & 0.000 & 0.003 & 0.000 & 0.004 \\
\hline $\mathrm{Mn}$ & 0.003 & 0.003 & 0.002 & 0.001 & 0.001 & 0.001 & 0.004 & 0.004 & 0.004 & 0.004 \\
\hline $\mathrm{Ca}$ & 0.831 & 0.828 & 0.817 & 0.853 & 0.839 & 0.844 & 0.841 & 0.810 & 0.855 & 0.806 \\
\hline $\mathrm{Na}$ & 0.096 & 0.095 & 0.091 & 0.098 & 0.110 & 0.094 & 0.099 & 0.086 & 0.105 & 0.088 \\
\hline Sum & 1.000 & 1.000 & 1.000 & 1.000 & 1.000 & 1.000 & 1.000 & 1.000 & 1.000 & 1.000 \\
\hline Wo $(\%)$ & 45.98 & 45.67 & 44.86 & 47.47 & 47.40 & 46.72 & 46.79 & 44.06 & 47.99 & 43.85 \\
\hline En & 53.05 & 53.92 & 53.44 & 51.88 & 51.94 & 53.12 & 53.01 & 54.36 & 51.77 & 54.13 \\
\hline Fs & 0.97 & 0.41 & 1.70 & 0.64 & 0.66 & 0.16 & 0.20 & 1.58 & 0.24 & 2.03 \\
\hline Vcell $(\AA)$ & 436.107 & 436.029 & 436.143 & 436.27 & 435.829 & 436.522 & 436.19 & 436.074 & 436.051 & 436.042 \\
\hline $\mathrm{V}_{\mathrm{M} 1}(\AA)$ & 11.5544 & 11.5344 & 11.5713 & 11.5484 & 11.5209 & 11.5803 & 11.5651 & 11.5511 & 11.5267 & 11.5433 \\
\hline
\end{tabular}

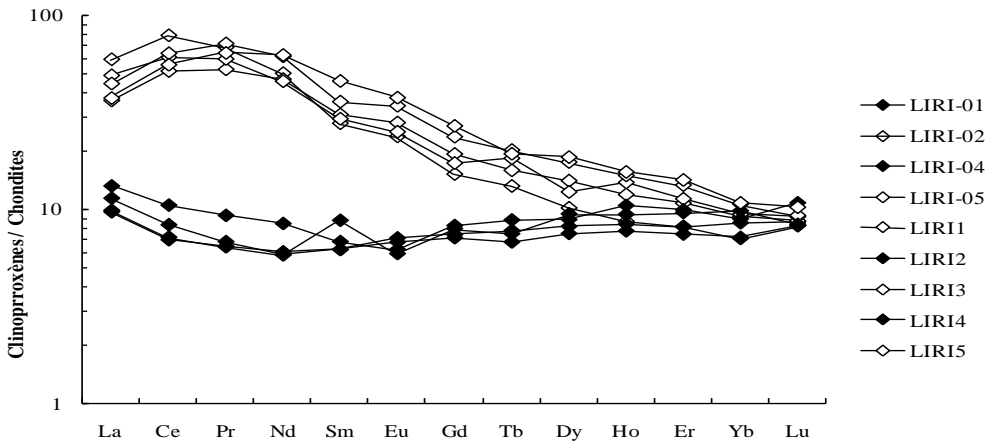

Fig. 3: Normalized REE Patterns of the Studied Clinopyroxenes From the Xenoliths from Liri (White Square for Group I And Black Square for Group II). Values Are Normalized to Chondrites [10].

Indeed, the clinopyroxene crystals of group-I are enriched in LREE and the patterns display a convex shape. However, the patterns of the group-II are more or less flat and low. The heavy rare earth contents (Er, Yb) are homogeneous for both groups (I and II). The Ti/Zr, $\mathrm{Sm} / \mathrm{Dy}, \mathrm{Ce}_{\mathrm{N}} / \mathrm{Yb}_{\mathrm{N}}, \mathrm{La} / \mathrm{Sm}, \mathrm{Sm} / \mathrm{Yb}$ and $\mathrm{La} / \mathrm{Yb}$ ratios (see Table 2) are similar in each group and entirely different from group I to group II. The $\mathrm{Ce}_{\mathrm{N}} / \mathrm{Yb}_{\mathrm{N}}$ ratio is high in the clynopyroxene of group I and low for the group II.

Table 2: A) Trace Elements of the Analyzed Clinopyroxene from Liri Spinel-Lherzolite

\begin{tabular}{|c|c|c|c|c|c|c|c|c|c|c|c|c|}
\hline Samples & $\mathrm{La}$ & $\mathrm{Ce}$ & $\mathrm{Sr}$ & $\mathrm{Nd}$ & $\mathrm{Zr}$ & $\mathrm{Sm}$ & $\mathrm{Eu}$ & $\mathrm{Gd}$ & $\mathrm{Ti}$ & Dy & $\mathrm{Er}$ & $\mathrm{Yb}$ \\
\hline LIRI-01 & 11.427 & 8.322 & 49.450 & 5.818 & 10.320 & 6.193 & 6.768 & 7.126 & 1723.940 & 7.499 & 7.445 & 7.151 \\
\hline LIRI-02 & 59.310 & 78.863 & 207.230 & 50.243 & 48.510 & 27.736 & 23.696 & 15.158 & 745.460 & 10.136 & 8.087 & 7.046 \\
\hline LIRI-04 & 9.655 & 6.946 & 45.960 & 6.012 & 11.430 & 6.193 & 7.089 & 7.375 & 1874.840 & 8.138 & 8.131 & 8.486 \\
\hline LIRI-05 & 36.557 & 51.790 & 130.960 & 47.038 & 39.470 & 30.931 & 28.125 & 19.379 & 2527.290 & 14.133 & 10.824 & 9.280 \\
\hline LIRI1 & 49.041 & 60.925 & 163.110 & 45.800 & 40.490 & 29.368 & 25.179 & 17.396 & 2057.800 & 12.361 & 11.391 & 9.477 \\
\hline LIRI2 & 13.251 & 10.527 & 55.550 & 8.444 & 15.780 & 6.798 & 6.196 & 8.240 & 2339.610 & 8.859 & 9.943 & 8.923 \\
\hline LIRI3 & 44.440 & 63.727 & 154.250 & 61.472 & 58.450 & 35.826 & 34.107 & 23.601 & 2790.920 & 17.470 & 13.279 & 10.585 \\
\hline LIRI4 & 9.885 & 7.162 & 43.450 & 5.791 & 9.570 & 8.770 & 5.875 & 7.935 & 2119.660 & 9.477 & 9.629 & 9.846 \\
\hline LIRI5 & 37.665 & 56.018 & 143.590 & 62.843 & 59.730 & 46.159 & 37.857 & 27.060 & 2924.750 & 18.665 & 14.223 & 10.831 \\
\hline
\end{tabular}

Table 2: B) Ratio of Some Analyzed Chemical Element from Liri Clinopyroxene.

\begin{tabular}{|c|c|c|c|c|c|c|}
\hline Samples & $\mathrm{Ti} / \mathrm{Zr}$ & $\mathrm{Sm} / \mathrm{Dy}$ & $\mathrm{Ce}_{\mathrm{N}} / \mathrm{Yb}_{\mathrm{N}}$ & $\mathrm{La} / \mathrm{Sm}$ & $\mathrm{Sm} / \mathrm{Yb}$ & $\mathrm{La} / \mathrm{Yb}$ \\
\hline LIRI-01 & 167.05 & 0.826 & 1.110 & 1.845 & 0.866 & 1.598 \\
\hline LIRI-02 & 15.367 & 2.736 & 7.780 & 2.138 & 3.936 & 8.417 \\
\hline LIRI-04 & 164.03 & 0.761 & 0.854 & 1.559 & 0.730 & 1.138 \\
\hline LIRI-05 & 64.031 & 2.189 & 3.665 & 1.182 & 3.333 & 3.939 \\
\hline LIRI1 & 50.822 & 2.376 & 4.929 & 1.670 & 3.099 & 5.175 \\
\hline LIRI2 & 148.26 & 0.767 & 1.188 & 1.949 & 0.762 & 1.485 \\
\hline LIRI3 & 47.749 & 2.051 & 3.648 & 1.240 & 3.385 & 4.199 \\
\hline LIRI4 & 221.49 & 0.925 & 0.756 & 1.127 & 0.891 & 1.004 \\
\hline LIRI5 & 48.966 & 2.473 & 3.001 & 0.816 & 4.262 & 3.478 \\
\hline
\end{tabular}

\section{Discussion}

The investigations of trace elements in single grain clinopyroxenes provide reliable information about chemical composition. The traceelements composition of clinopyroxene analyzed in spinel-lherzolite xenoliths from Liri is therfore a useful indicator of chemical 
modification in the mantle. Thus, ion microprobe investigation allowed two groups incompatibility diagrams in Liri clinopyroxenes to be distinguished (Fig. 3). The first one is highly LREE-enriched $\left(\mathrm{Ce}_{N} / \mathrm{Yb}_{\mathrm{N}}\right.$ : from 3.00 to 7.78). The second one has concave-upward REE patterns $\left(\mathrm{Sm}_{\mathrm{N}} / \mathrm{Dy}_{\mathrm{N}}\right)$ and is less LREE-enriched $\left(\mathrm{Ce}_{\mathrm{N}} / \mathrm{Yb}_{\mathrm{N}}\right.$ : from 0.75 to 1.18). According to [11], for peridotites that do have LREE-depleted clinopyroxenes, a correlation of HREE with other incompatible trace elements (e.g., strontium, zirconium) requires fractional melting to be the principal means of depletion in the mantle.

The slight depletion of rare earths elements in the analyzed clinopyroxenes (Liri 01, Liri 2, Liri 04, Liri 4) compared with the other REE observed in the others clinopyroxenes from Liri is indicative of a partial melting episode, whereas light rare earth elements enrichments observed for other samples (Liri 1, Liri 02, Liri 3, Liri 05 and Liri 5) are significant for cryptic metasomatism [12]. It is probably a cryptic metasomatism due to the absence of hydrated minerals (such as amphibole).

It is suggested that this enrichment in light rare earth element (LREE), at times, is closely related to the host alkali basaltic volcanism. The host xenoliths of studied clinopyroxenes have had a substantial component of mantle metasomatism that dominates partial melting and basaltic extraction effects. Incompatibility diagrams clearly demonstrate that clinopyroxenes have been in part modified or produced by mantle metasomatism.

Our results are similar to those described by [13], that clinopyroxenes which survived larger degrees of melting were easily enriched by the successive interaction with metasomatic agents due to the more appropriate site volumes, we suggest also that crystal chemistry and trace-element variations of clinopyroxenes from group I and group II are the result of highly complex processes including: 1) partial melting at different depths, 2) crystallization from alkaline magmas, cryptic metasomatism by 3) alkaline magmas. And then we can imagine that during metasomatism of group I and group II, clinopyroxenes incorporated significants amounts of LREE and $\mathrm{Sr}$ (interaction with alkaline melts), $\mathrm{Zr}$ (interaction with alkaline melts), but not Ti. However, present data indicate that the mineral chemistry of clinopyroxenes may be also significantly modified by interaction with alkaline. A remarkable feature in the variation of REE shows the depletion of higher rare earths elements (HREE), interpreted as absence of garnet in the source liquid.

\section{Conclusion}

Spinel-lherzolite xenoliths from Liri (south of the Kapsiki Plateau) have a protogranular texture with the particular clinopyroxenes composition. Two clinopyroxenes groups have been identify according to their trace-elements compositions. In some crystals (group I) the trace elements are enriched than in the others (group II). The slight depletion of REE in the group II clinopyroxene from Liri is indicative of a partial melting episode. However, the LREE enrichments observed in the others samples (group II) are significant for cryptic metasomatism.

\section{References}

[1] Ngounouno, I., Dagwaï, N., Kamgang, P. and Deruelle, B. (2008) Petrology of Spinel Lherzolite Xenoliths in Alkali Basalts from Liri, South of the Kapsiki Plateau (Northernmost Cameroon Hot Line). Journal of Cameroon Academy of Science, 8, 31-42.

[2] Dal Negro, A., Carbonin, S., Domeneghetti, C., Molin, G.M., Cundari, A.and Piccirillo, E.M. (1984) Crystal chemistry and evolution of the clinopyroxene in a suite of high pressure ultramafic nodules from the Newer Volcanics of Victoria, Australia. Contrib Mineral Petrol 86: $221 \pm 229$ https://doi.org/10.1007/BF00373667.

[3] Cundari, A., Dal Negro, A., Piccirillo, E.M., Della Giusta, A. and Secco, L. (1986) Intracrystalline relationships in olivine, pyroxenes and spinel from a suite of spinel lherzolite xenoliths from Mt. Noorat, Victoria, Australia. Contrib. Mineral. Petrol. 94, 523-532 https://doi.org/10.1007/BF00376343.

[4] Ngounouno, I., Déruelle, B. and Demaiffe, D. (2000) Petrology of the bimodal Cenozoic volcanism of the Kapsiki plateau (northern most Cameroun, central Africa), J. Volcanol. Geotherm. Res. 102, 21-44. https://doi.org/10.1016/S0377-0273(00)00180-3.

[5] Dunlop, H.M. (1983) Strontium isotope geochemistry and potassium-argon studies on volcanic rocks from the Cameroon line, West Africa. PhD thesis, Univ. Edingburgh, $347 \mathrm{pp}$

[6] Vincent, P.M. and Armstrong, R.L. (1973) Volcanism of the Kapsiki Plateau (North Cameroon) and the underlying sedimentary formations. Coll. African Geol., Florence, abst., unpubl.

[7] Tamen, J., 1998. Contribution à l'étude géologique du plateau Kapsiki (Extrême-Nord, Cameroun): Volcanologie, Pétrologie et Géochimie. Thèse Doct. 3ème cycle, Université de Yaoundé 1, 127pp.

[8] Ngounouno I (1993) Pétrologie du magmatisme cénozoïque de la vallée de la Bénoué et du plateau Kapsiki (nord du Cameroun). Thèse Doct. Université Pierre et Marie Curie, Paris, pp 1-280

[9] Ngounouno, I. and Déruelle, B. (2007) Petrology of wehrlites and clinopyroxenites xenoliths from Mount Cameroon: Evidence of mantle metasomatism. Journal of Cameroon Academy of Science, 7, 35-46.

[10] Anders, E. and Grevesse, N., 1989. Abundances of the elements: Meteoritic and solar. Geochim. Cosmochim. Acta, 53,197-214. https://doi.org/10.1016/0016-7037(89)90286-X

[11] Norman, M. (2001) Application of laser-ablation ICPMS to the trace element geochemistry of basaltic magmas and mantle evolution. Inn Min Assoc. Can. Short Course series (ed. P. Sylvester) Ottawa, 29, 163-184.

[12] Grégoire, B.N., Moine, S.Y., O’Reilly, J.-Y., Cottin, A. and Giret, 2000. Trace element residence and partitioning in mantle xenoliths metasomatized by highly alkaline, silicate and carbonate rich melts (Kerguelen Islands, Indian Ocean), J. Petrol., 41, 477-509. https://doi.org/10.1093/petrology/41.4.477.

[13] Yaxley, G.M., Crawford, A.J. and Green, D.H. (1991) Evidence for carbonatite metasomatism in spinel peridotite xenoliths from western Victoria, Australia, Earth Planet. Sci. Lett., 107, 305-317. https://doi.org/10.1016/0012-821X(91)90078-V. 